\title{
Reference
}

NBSIR 83-2756

\section{A Laboratory Investigation of Refrigerant Migration in A Split Unit Air Conditioner}

U.S. DEPARTMENT OF COMMERCE National Bureau of Standards Center for Building Technology Washington, DC 20234

April 1983

Issued August 1983

Prepared for:

U.S. Department of Energy Office of Conservation and Renewable Energy Vashington, DC 20585 

NBSIR 83-2756

A LABORATORY INVESTIGATION OF

REFRIGERANT MIGRATION IN A SPLIT

UNIT AIR CONDITIONER

William J. Mulroy

David A. Didion

U.S. DEPARTMENT OF COMMERCE

National Bureau of Standards

Center for Building Technology

Washington, DC 20234

April 1983

Issued August 1983

Prepared for:

U.S. Department of Energy

Office of Conservation and

Renewable Energy

Washington, DC 20585

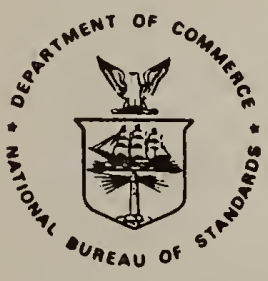

U.S. DEPARTMENT OF COMMERCE, Malcolm Baldrige, Secretary NATIONAL BUREAU OF STANDARDS. Ernest Ambler, Director 

The relationship between cyclic refrigerant migration and cyclic loss for a residential, split-system air conditioner has been investigated. The cyclic refrigerant migration was measured at different points in the operating cycle by simultaneously shutting five pneumatic valves which isolated the refrigerant in the major system components. The refrigerant was then removed, weighed, and returned to the system. The unit tested was found to have a high initial capacity as migrated refrigerant was removed from the evaporator and then a low, slowly increasing capacity as trapped refrigerant was returned to the system from the accumulator. The unit performance was also compared to single and double time constant regressive approximations and to the time constant calculated from the evaporator mass and heat transfer coefficient. Although relationships between migrated refrigerant and cyclic capacity were observed, no practical refrigerant migration test method that would be less burdensome than the cyclic tests of ASHRAE Std. 116 appears possible at this time.

Key Words: Central air conditioners; cyclic testing; heat pumps; refrigerant migration 

List of Tables... . . . . . . . . . . . . . . . . vii

List of figures . . . . . . . . . . . . . . . . . . ix

Metric Conversion Factors . . . . . . . . . . . . . . . xi

1. INTRODUCTION . . . . . . . . . . . . . . . . . . . 1

2. TEST SPECIMEN AND FACILITY . . . . . . . . . . . . 3

3. TEST PROCEDURE . . . . . . . . . . . . . . . . . . 9

4. DETERMINATION OF COOLING CAPACITY, PART LOAD FACTOR, AND REFRIGERANT MASS IN ISOLATED SECTIONS . . . . . . . . . . . . 14

5. DISCUSSION OF RESULTS . . . . . . . . . . . . . . 16

6. CONCLUSIONS . . . . . . . . . . . . . . . . 33

7. REFERENCES . . . . . . . . . . . . . . . . . . 35

APPENDIX A: Comparison of Cyclic Performance to Reduced

Charge Steady-State Performance . . . . . . . . 36

APPENDIX B : Refrigerant Migration Measurement Techniques . . . . . . 40 



\section{LIST OF TABLES}

TABLE 1. COMPONENT VOLUME MEASUREMENTS . . . . . . . . . . . . . . 5

TABLE 2. COMPONENT MASS MEASUREMENTS . . . . . . . . . . . . . . 5

TABLE 3. SUMMARIZED STEADY-STATE TEST RESULTS . . . . . . . . . . . 17

TABLE 4. SUMMARIZED CYCLIC TEST RESULTS . . . . . . . . . . . . 18

TABLE 5. REFRIGERANT CONTENT OF ISOLATED SECTIONS $\quad$. . . . . . . . . . 19

TABLE 6. POUNDS OF LIQUID AND VAPOR IN ISOLATED SECTIONS

(CALCULATED FROM LIQUTD AND VAPOR DENS ITIES,

ISOLATED SECTION VOLUMES AND DATA OF TABLE 3) . . . . . . . 20 

Figure 1. Schematic of NBS Heat Pump Test Apparatus . . . . . . . . . . 4

Figure 2. Refrigerant Migration During an "On" Cycle . . . . . . . . 21

Figure 3. Comparison of Time for Capacity to Reach Steady-State to Time Required to Empty Accumulator . . . . . . . . . 24

Figure 4. Comparison of Transient Air-Side Capacity to Coincident Transient Refrigerant Side Capacity . . . . . . 25

Figure 5. Comparison of Refrigerant Side Capacity to Refrigerant Mass in Evaporator . . . . . . . . . . 27

Figure 6. Regressive Fit to Experimental Transient Normalized Capacity Data . . . . . . . . . . . . . 29

Figure 7. Capacity Decay after Compressor Shut-off with Continuous Fan Operation .............. 31

Figure Al. Unit Capacity as a Function of Charge . . . . . . . . . 37

Figure A2. Comparison of Refrigerant Side Capacity to Capacity

Calculated from Accumulator Content and Reduced

Charge Steady-State Data . . . . . . . . . . 38

Figure A3. Comparison of Air Side Capacity Calculated from Accumulator Liquid Charge and Reduced Charge Steady-State Data to Experimental Air Side Data . . . . . . 39 



$\begin{array}{ll}\text { Length } & \begin{array}{l}1 \text { inch }(\mathrm{in})=25.4 \mathrm{milimeters}(\mathrm{mm}) \\ 1 \mathrm{foot}(\mathrm{ft})=0.3048 \text { meters (m) }\end{array} \\ \begin{array}{ll}\text { Area } \\ \text { Volume }\end{array} & 1 \mathrm{ft}^{2}=0.092903 \mathrm{~m}^{2} \\ \text { Temperature } & \mathrm{F}=9 / 5 \mathrm{C}+32 \\ \begin{array}{l}\text { Temperature } \\ \text { Interval }\end{array} & 1 \mathrm{I}^{\circ} \mathrm{F}=9 / 5^{\circ} \mathrm{C} \\ \begin{array}{l}\text { Mass } \\ \text { Mass Per Unit Volume }\end{array} & 1 \mathrm{pound}(1 \mathrm{~b})=0.453592 \mathrm{kilograms}(\mathrm{kg}) \\ \text { Energy } & 1 \mathrm{Btu}=1.05506 \mathrm{kilojoules}(\mathrm{kJ}) \\ \text { Specific Heat } & \left.1 \mathrm{Btu} /\left[(1 \mathrm{~b})\left({ }^{\circ} \mathrm{F}\right)\right]=4.1868 \mathrm{~kJ} / \mathrm{I}(\mathrm{kg})\left({ }^{\circ} \mathrm{K}\right)\right] \\ \text { Gallon } & 1 \mathrm{gallon}=0.0037854 \mathrm{~m}^{3}\end{array}$





\section{INTRODUCTION}

Because of the concerns about test cost and testing time requirements of the current evaluation procedure for central air conditioners, the Department of Energy (DoE) requested the National Bureau of Standards (NBS) to investigate severa1 alternative approaches for determining cyclic degradation that might result in a simpler, cheaper test procedure without sacrifice of repeatability or of comparability to results obtained currently.

Laboratory and field tests have shown that units which do not allow off-cycle refrigerant migration (i.e., units with thermostatic expansion valves without bleed ports) have less performance degradation when cycling than do units which allow off-cycle pressure equalization and consequent refrigerant migration. As a result the existing cyclic test procedures were conceived to allow for credit to be given for those designs that might minimize cyclic losses. Modeling efforts which might be used to mitigate some of the testing requirements were thwarted since the amount of migration varies from one design to another and is also function of operating conditions. Therefore, it was not possible to characterize an air conditioner by a simple time constant as was done for the furnace/boiler evaluation procedure. Theoretical approaches to cyclic performance analysis have been presented which use refrigerant migration during the off-cycle as an input [1] [2]. However, no adequate empirical data has existed, in the public domain, to quantify the refrigerant flow during the dynamic periods of a typical air conditioner operation.

This report presents results of dry coil steady-state and comparable cyclic tests performed at the DoE/NBS test procedure [3] rating point $\left(27.8^{\circ} \mathrm{C}\right.$ or $82^{\circ} \mathrm{F}$ outdoor 
temperature) using the recently introduced continuous indoor fan option for the cyclic tests. The refrigerant mass in flve major areas (compressor and accumulator, liquid line, vapor line, condenser, evaporator) was determined by shutting quick closing pneumatic ball valves isolating these areas and then extracting and welghing the refrigerant contained in each. Refrigerant mass distribution data were taken for steady-state operation and at the beginning, end (6-minutes) and at several intermediate times during an "on" cycle performed as an extension of 6 minute "on" and 24 minute "off" cyclic tests performed in accordance with the DoE/NBS test procedure [3].

No adequately confirmed theoretical model for calculating the cyclic degradation factor from this experimental data or recommended alternate test procedure is presented at this time. This empirical study indicates that such a procedure may be possible; although the representative function will be more than a simple time constant and the method for obtaining the test data may not be less burdensome than the current test methods. 


\section{TEST SPECIMEN AND FACILITY}

A nominal three ton, split system, air-to-air unitary heat pump operated in the cooling mode was used for this investigation. The unit, being a heat pump, differed from a typical split system air conditioner in its coil sizing and in possessing a four way valve and an accumulator. These design changes generally result in a heat pump having a lower steady-state efficiency and a greater cyclic degradation coefficient than that of a central air conditioner of similar cooling capacity. It was believed that this expected increase in the variable to be studied, the cyclic degradation factor, would increase the measurement accuracy. The unit was equipped with a crankcase heater which was automatically energized during all "off" cycles. The outdoor unit contained the compressor, outdoor coil, fan defrost controller and associated equipment. The indoor and outdoor sections of the heat pump were installed in separate but adjoining environmental chambers.

System measurements not generally considered in a performance test, but of particular interest in this study were the volumes and masses of various system components some of which are summarized in Tables 1 and 2 . The volume measurements in Table 1 listed as experimental were determined by vapor charging the system component vdlumes isolated by pneumatically operated ball valves (Fig. 1) with refrigerant 22 . The system volumes were then calculated from the specific volumes of the thermally stabilized refrigerant in each section (taken from the R22 superheat tables at the measured temperatures and pressures) and the measured refrigerant mass introduced by taking before and after charging cylinder weights (correcting for charging hose volume). As a check, comparable volumes listed as dimensional in Table 1 were calculated from 


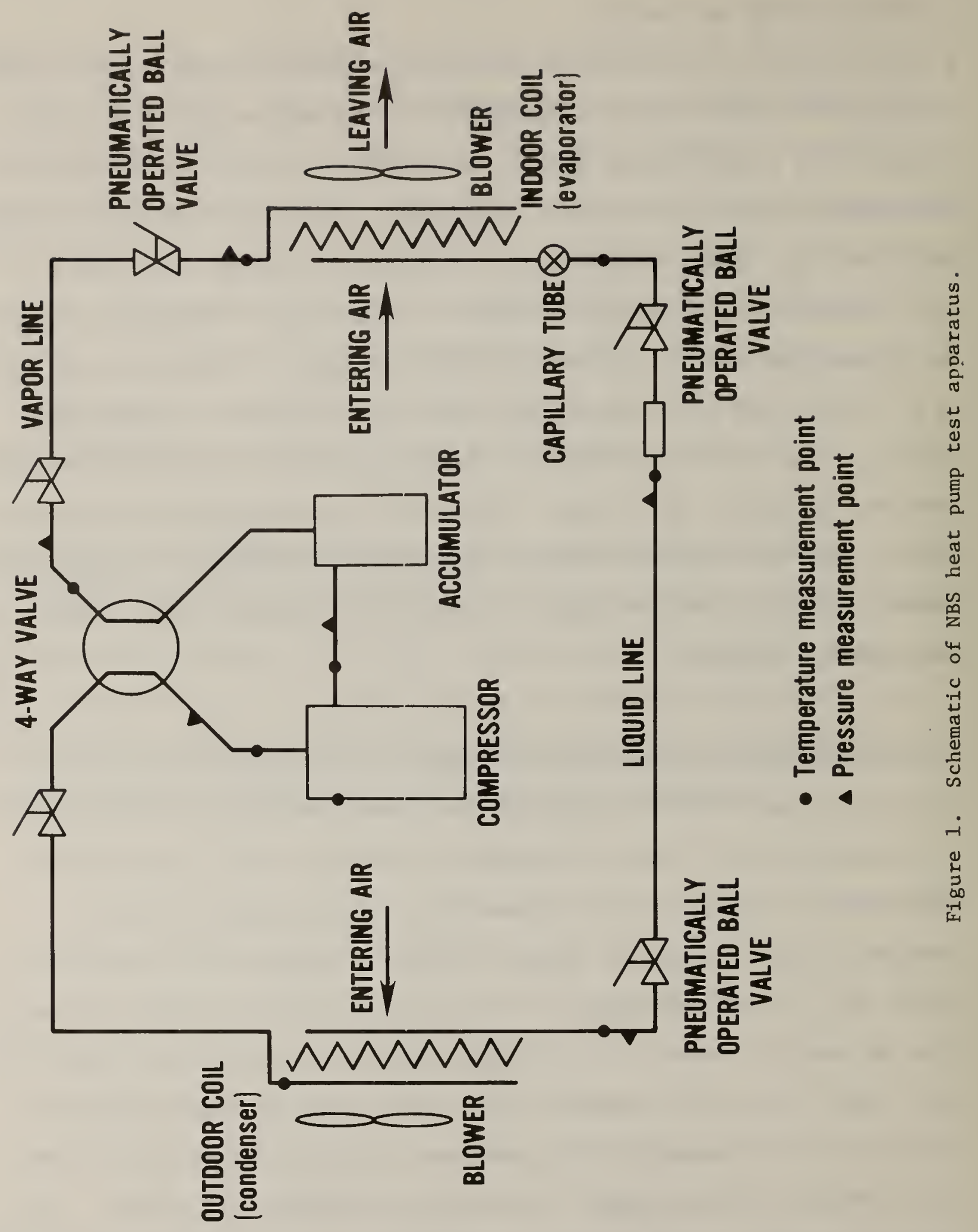


tubing lengths, outside diameters and presumed wall thicknesses for all components except the compressor-accumulator section which was too complex to allow a reasonably accurate volume estimate from the available dimensional data.

Table 1

Component Volume Measurements

$\begin{array}{lcc} & \text { Dimensional } & \text { Experimental } \\ \text { Outdoor Coil } & 4310 \mathrm{~mL}\left(263 \mathrm{in}^{3}\right) & 5020 \mathrm{~mL}\left(306 \mathrm{in}^{3}\right) \\ \text { Compressor and Accumulator } & - & 10,000 \mathrm{~mL}\left(610 \mathrm{in}^{3}\right) \\ \text { Vapor Line } & 1000 \mathrm{~mL}\left(61 \mathrm{in}^{3}\right) & 870 \mathrm{~mL}\left(53 \mathrm{in}^{3}\right) \\ \text { Liquid Line } & 1030 \mathrm{~mL}\left(63 \mathrm{in}^{3}\right) & 1280 \mathrm{~mL}\left(78 \mathrm{in}^{3}\right) \\ \text { Indoor Coil } & 5150 \mathrm{~mL}\left(314 \mathrm{in}^{3}\right) & 5760 \mathrm{~mL}\left(346 \mathrm{in}^{3}\right)\end{array}$

The component mass measurements given in Table 2 were calculated using the dimensional data used in preparing Table 1 with the addition of measurements of the coil fin dimensions.

Table 2

Component Mass Measurements

$\begin{array}{lr}\text { Outdoor Coil } & 12.4 \mathrm{~kg}(27.4 \text { pounds }) \text { of copper } \\ 11.4 \mathrm{~kg}(25.1 \text { pounds }) \text { of aluminum } \\ \text { Indoor Coil } \\ 16.7 \mathrm{~kg}(36.7 \text { pounds }) \text { of copper } \\ 8.9 \mathrm{~kg}(19.6 \text { pounds }) \text { of aluminum } \\ \text { Vapor Line } & 3.0 \mathrm{~kg}(6.5 \text { pounds }) \text { of copper }\end{array}$

The unit was tested in the environmental chambers and apparatus described in [5]. 
The principal method used to measure the heat pump heating and sensible cooling capacities was the indoor air enthalpy method. An air flowrate measuring apparatus was connected to an insulated duct attached to the discharge side of the Indoor section of the heat pump. This apparatus consisted of a receiving chamber and discharge chamber separated by a partition containing a nozzle. An exhaust fan was attached to the duct leaving the discharge chamber so that the static pressure of the air leaving the indoor section of the heat pump could be adjusted to give air flow rates consistent with the manufacturer's performance data.

Manometers accurate to within $1 \%$ of the reading were used to measure static pressure across the nozzle and pressures obtained by a pitot tube placed at the nozzle exit. A thermocouple was installed to determine the air temperature at the nozzle exit.

A thirty-junction thermopile was constructed to measure the air temperature difference entering and leaving the indoor section of the heat pump. One side of the thermopile was placed in the entering duct while the other was placed in the insulated discharge duct leading to the receiving chamber of the air flow measuring apparatus. The junctions of the thermopile were spaced at centers of equal area across the inlet and discharge ducts. The millivolt signal generated by the thermopile was integrated by an electronic integrator in order to obtain time-temperature difference data of the air passing over the indoor coil. A duplicate thermopile was read as point data for integration by use of Simpon's rule and for preparation of the graphical presentations of capacity as a function of time in this report. 
The relative humidity of the air entering the indoor unit was measured by a motorized psychrometer. A motorized psychrometer was also used to measure the relative humidity of the air leaving the indoor unit.

The volatile refrigerant flow method [6] was used as the secondary test to determine the full-load, steady-state cooling capacities. The liquid refriggerant line at the indoor unit was modified to incorporate a sightglass, turbine meter and four valves. The valves served to properly direct the flow of refrigerant through the turbine meter when the heat pump operated in either the heating or cooling mode. All tests discussed in this report were performed in the cooling mode.

Adequate subcooling at the turbine meter was necessary for accurate determination of the refrigerant flowrate. For this reason, it was not possible to use this secondary method for part load tests. The refrigerant flow was determined by the turbine meter and electronic totalizer. The density of the refrigerant was determined from the temperature and pressure readings.

Watthour meters were installed to measure the electrical energy consumption of the compressor and outdoor fan, and the indoor fan. Electronic totalizers and printers were connected to the watthour meters to provide a record of the energy consumption.

The dry-bulb and dew-point temperatures in both the indoor and outdoor environmental chambers were continuously recorded. The average temperatures of the air entering the outdoor unit was measured using four thermocouples connected in parallel. In addition to the preceding instrumentation, thermocouples and pressure gages were installed at various locations and temperatures and 
pressures were recorded to provide additional information on the performance of the unit and as a check for consistent operation.

Electric resistance heaters which cycled "on" or "off" as the unit cycled were installed in the test chamber to stabilize the load on the test chamber environmental control systems.

Pneumatically-operated ball valves operated by a solenoid pilot were installed in the locations shown schematically in figure 1 so that portions of the system could be isolated and their refrigerant content determined by transferring the refrigerant to a canister and determining the change in refrigerant container weight. 


\section{TEST PROCEDURE}

Prior to each day's testing, the unit was vapor charged with the same amount of refrigerant that was removed after the previous day's test.

In later tests it was found to be simplest and most accurate to charge the unit to a repeatable steady-state performance after test room conditions had been obtained. In this case the refrigerant flowrate was the observed quantity. When this method was used, the refrigerant cylinder was weighed before and after charging to compare the amount of refrigerant removed at the end of the test.

Vapor charging, because of the reduced charging line tare, was found to be considerably more accurate than liquid charging. However, the best measure of the weight of refrigerant added was that observed when the cylinder was detached from the charging manifold. The best step-by-step procedure for charging by weight was as follows:

1) The desired amount of refrigerant to be added was determined.

2) The refrigerant cylinder was weighed.

3) The upright refrigerant cylinder was placed in a bucket of slightlybelow-room-temperature water to maintain a constant pressure as refrigerant was evaporated into the system. The cylinder and the water filled bucket were mounted on a platform scale. 
4) Using a refrigerant charging manifold, the cylinder was connected to the low pressure side of the unit and to a vacuum pump.

5) After the manifold was evacuated, the vacuum pump was isolated and disconnected.

6) The cylinder valve was opened and the manifold and tubing were pressurized to a value near the expected steady-state suction pressure.

7) The manifold to cylinder hose was adequately supported to prevent indicated weight changes as a result of tank or hose motion.

8) The platform scale was balanced.

9) The scale arm was set to desired final weight.

10) The unit valve was opened until tank pressure was reached.

11) The heat pump was started and the valves were closed when scale arm fell.

12) The refrigerant cylinder was detached from the unit, removed from the water bath, the outside dried, and weighed. 
The most accurate measurement of the amount of refrigerant added is the difference between the cylinder weights taken in steps 2 and 12 . A consistent bias error of approximately $23 \mathrm{~g}(0.05$ pounds) between the refrigerant added and the amount removed was observed during preliminary tests and was used in the calculation of the charge to be added when this method vas used.

It was found that the unit performance for equal calculated total charges would be different if charged from a vacuum as opposed to charging from a residual vapor charge. In this case the unit charged from an evacuated state would be undercharged because of refrigerant absorption by the crankcase oil. For all tests in this report the unit was charged from a residual vapor charge that would result in a quantity of refrigerant absorbed in the oil near the steady-state value. The steady-state suction pressure was approximately $550 \mathrm{kPa}(65 \mathrm{psig})$. The refrigerant was extracted with a cylinder packed in water ice $\left(0^{\circ} \mathrm{C}\left[32^{\circ} \mathrm{F}\right]=465 \mathrm{kPa}[52.8 \mathrm{psig}]\right.$ saturation pressure).

When steady-state operation of the unit and test chamber reached the $27.8^{\circ} \mathrm{C}$ $\left(82^{\circ} \mathrm{F}\right)$ dry coil test condition of the DoE/NBS test procedure, data were taken for a minimum period of $1 / 2$ hour. For the three tests reported as QC 3 , QC 5, and QC 6 in Table 3, the unit was shut off and the pneumatically operated valves simultaneously closed at the end of the steady-state data period. For the 
other reported tests, manually-operated cyclic operation was begun at the end of the steady-state data period. These cyclic tests were performed following the guidelines of the DoE/NBS test procedure using the 6 minute "on" cycle length and 24 minute "off" cycle length. All tests were performed with continuous indoor fan operation (i.e., during both the "on" and "off" cycles).

Three complete cycles were performed to allow conditions to become repeatable in the cyclic mode. A fourth cycle was then performed during which DoE/NBS test procedure test data were taken. Following this "data" cycle an additional 24 minute "off" period followed by a 6 minute "on" period was performed. The pneumatically operated valves were closed at various times between cut-on and 6 minute of operation during this "on" period. The compressor was wired to stop simultaneously with pneumatically operated valve closure.

In all cases, closure of the pneumatic valves was immediately followed by extraction and weighing of the refrigerant in each isolated section according to the following procedure:

1) The cylinder to be used was weighed prior to refrigerant removal.

2) The upright refrigerant cylinder was placed in an ice bath.

3) One hose of a charging manifold was connected to the cylinder, another to the unit volume from which the refrigerant was removed, and the third to a vacuum pump. 
4) The manifold was evacuated and the isolation valve was closed. Then the vacuum pump was shut off and disconnected.

5) The valves on tank and unit were opened.

6) The pressure was observed, when pressure reached approximately 60 psig $(510 \mathrm{kPa}$ ) the tank and unit valves were shut.

7) The tank was disconnected from the manifold hose, removed from the ice bath, excess water was wiped off and the tank was weighed.

8) Steps 1 through 7 were repeated for each isolated area.

9) Approximately 1 hour after removal the pressures and temperatures of all isolated areas were checked to verify that they contained superheated vapor.

10) After temperatures were stabilized (preferably the next morning) the temperature and pressure of each isolated area was recorded so that the mass of vapor remaining in each section could be calculated. 
4. DETERMINATION OF COOLING CAPACITY, PART LOAD FACTOR, AND REFRIGERANT MASS IN ISOLATED SECTIONS

As previously noted, the test facility was designed for determining the sensible cooling capacity by the indoor air enthalpy method. As a check

on the measurement of the cooling capacity during steady-state, full-load operation, the volatile refrigerant flow method was used. The equations used for determining the cooling capacity are given in [6]. Since all reported tests were performed with a dry indoor coll (no latent capacity) the total cooling capacity was equal to the sensible cooling capacity.

The equations used for calculating the part load factor, PLF, and cyclic degradation factor $C_{D}$, are given in [3]. The test procedure for this report differed from [3] in having continuous operation of the indoor fan (i.e., during both "on" and "off" cycles) as proposed in the ASHRAE Standard 116P. The cooling done during cyclic operation was defined as that done during the 6 minute "on" cycle. No credit was given for the cooling that occurred during the first few minutes of the "off" cycle nor debit taken for the "off" cycle fan or crankcase heat. The unit "on" cycle power including "on" cycle fan power was used as the total cyclic power in calculating the coefficient of performance and cyclic performance degradation coefficient, $C_{D}$. The cyclic and comparable steady-state cooling capacities were calculated from both data taken by an electronic integrator reading and a 30 junction thermopile across the evaporator and by numerical integration of point data taken from a duplicate thermopile.

The refrigerant content of each isolated section, for the quick closing valve tests, was calculated as the weight removed plus the mass of the vapor remaining calculated from the section volume and the density of superheated 
vapor at the final pressure and temperature recorded after sufficient time had been allowed for these quantities to stabilize. The quality (mass fraction of vapor) in each isolated section was calculated from the above determined total refrigerant mass, the volume of each section, and from refrigerant vapor and liquid densities calculated from the pressures and temperatures occurring at the time of valve closure. In this case the vapor was assumed to be superheated at the average temperature of each section and the liquid was assumed to be saturated at the lowest temperature measured by any of the component thermocouples on that section, or if lower, the section saturation temperature corresponding to the measured pressure.

Only one test, QC 11, was performed with the unit indoor fan cycling with the compressor. This test was terminated at the end of a cut-off period with pneumatic isolation valve closure at that time. As can be seen in Tables 4 and 5 the off-cycle refrigerant migration for this cyclic fan test was not significantly different from the continuous fan test data. 


\section{DISCUSSION AND RESULTS}

The test results for the steady-state and cyclic periods preceeding pneumaticallyoperated valve closure are given in Tables 3 and 4.

The refrigerant migration data taken with the quick closing pneumaticallyoperated valve system are listed in Tables 5 and 6 and are plotted as a function of time in figure 2. Some comments which can be made about this data are:

1) Most of the refrigerant was on the high pressure side during steady-state operation. Approximately $46 \%$ of the total charge was in the condenser and $37 \%$ in the liquid line for a total of $83 \%$, the remaining $17 \%$ being on the low pressure side.

2) Most of the refrigerant was on the low pressure side at the end of the off-cycle. Approximately $56 \%$ of the total charge was in the evaporator, $2 \%$ in the vapor line, and $22 \%$ in the compressor and accumulator for a total of $80 \%$, the remaining $20 \%$ being on the high pressure side.

Refrigerant migration to the evaporator during the off-cycle was initially the result of the pressure gradient between the condenser and evaporator. After these pressures equalized, which was typically in about 5 minutes for this unit, migration continued as a result of the temperature gradient between the condenser and evaporator. The refrigerant migration to the accumulator during the off-cycle was presumably by gravity flow from the evaporator since the accumulator in the compressor compartment, was considerably warmer than the evaporator during the off-cycle. At the end of a typical off-cycle, temperatures of $34.5^{\circ} \mathrm{C}$ $\left(94.1^{\circ} \mathrm{F}\right)$ and $28.1^{\circ} \mathrm{C}\left(82.6^{\circ} \mathrm{F}\right)$ were recorded from insulated thermocouples soldered to the top and bottom of the accumulator respectively. This bottom temperature 


\begin{tabular}{|c|c|c|c|c|c|c|c|c|c|c|c|c|c|c|c|c|}
\hline 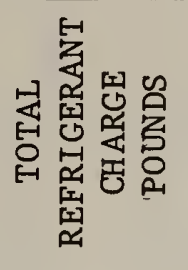 & $\begin{array}{l}* \\
\stackrel{q}{+} \\
\dot{0}\end{array}$ & $\begin{array}{l}7 \\
9 \\
\infty\end{array}$ & $\begin{array}{l}* \\
0 \\
0 \\
\infty\end{array}$ & $\stackrel{\dddot{n}}{\dddot{n}}$ & $\underset{\infty}{\stackrel{0}{r}}$ & $\begin{array}{l}* \\
\text { n } \\
\infty\end{array}$ & $\begin{array}{l}\pi \\
\text { in } \\
\infty\end{array}$ & $\begin{array}{l}\approx \\
\dot{v} \\
\infty\end{array}$ & $\begin{array}{l}n \\
\text { in } \\
\infty\end{array}$ & $\begin{array}{l}n \\
\text { in } \\
\infty\end{array}$ & \begin{tabular}{l}
$*$ \\
\multirow{\sigma}{*}{} \\
$\infty$
\end{tabular} & $\begin{array}{l}m \\
\ddot{b} \\
\infty\end{array}$ & $\begin{array}{l}* \\
\infty \\
\infty\end{array}$ & $\stackrel{m}{n}$ & 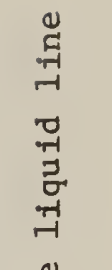 & $\begin{array}{l}0 \\
\pi \\
3 \\
5 \\
\pi \\
4 \\
4 \\
0 \\
0\end{array}$ \\
\hline 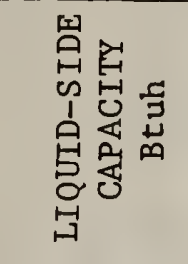 & $\begin{array}{l}\text { ్ } \\
\text { ํ. } \\
\text { ㄱ. }\end{array}$ & $\begin{array}{l}\text { ㅇ } \\
\text { ণे } \\
\text { 이 }\end{array}$ & $\begin{array}{l}\text { 우 } \\
\text { ○े } \\
\text { r }\end{array}$ & $\begin{array}{l}\text { 옹 } \\
\text { ㅇํ }\end{array}$ & 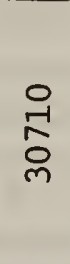 & 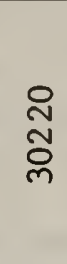 & $\begin{array}{l}\circ \\
\text { o } \\
\text { 요 }\end{array}$ & $\begin{array}{l}\text { 엄 } \\
\text { 공 }\end{array}$ & $\begin{array}{l}\text { ᄋ } \\
\text { ఫे } \\
\text { ু }\end{array}$ & ๙ & $\begin{array}{l}\text { ㅇ } \\
\text { } \\
\text { సे }\end{array}$ & $\begin{array}{l}\text { ్ } \\
\text { 。ั }\end{array}$ & $\begin{array}{l}\text { 옹 } \\
\text { ๙ิ }\end{array}$ & 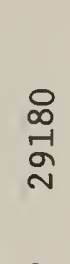 & 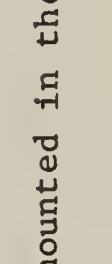 & 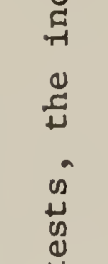 \\
\hline 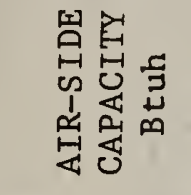 & 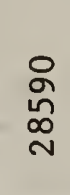 & $\begin{array}{l}\text { 오 } \\
\text {-ु } \\
\text { 유 }\end{array}$ & $\begin{array}{l}\text { ్ㅠ } \\
\text { నે }\end{array}$ & $\begin{array}{l}\text { ㅇ } \\
\text { ఫे } \\
\text { Iิ }\end{array}$ & 옳 & $\begin{array}{l}\text { ్ } \\
\infty \\
\text { ๙ } \\
\text { ㄱ. }\end{array}$ & $\underset{\substack{\mathfrak{n} \\
\underset{N}{N}}}{\stackrel{0}{N}}$ & 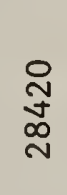 & $\begin{array}{l}0 \\
\infty \\
0 \\
\infty \\
\sim\end{array}$ & 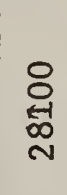 & 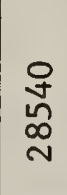 & $\begin{array}{l}0 \\
\infty \\
0 \\
\infty \\
\text { N }\end{array}$ & $\begin{array}{l}\text { 尺 } \\
\infty \\
\infty \\
\sim \\
\sim\end{array}$ & 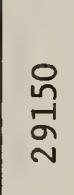 & 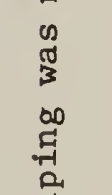 & 峁 \\
\hline 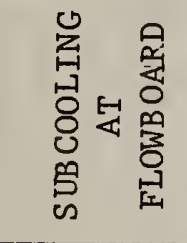 & $\begin{array}{l}L_{1} \\
0 \\
\vdots \\
0 \\
0\end{array}$ & $\begin{array}{l}{[1} \\
0 \\
\infty \\
-1 \\
-1\end{array}$ & 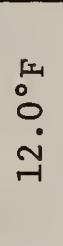 & $\begin{array}{l}I_{1} \\
0 \\
\text { H-1. } \\
-1 \\
\text { न- }\end{array}$ & $\begin{array}{l}f x \\
\dot{f x} \\
\dot{v} \\
\dot{+1}\end{array}$ & 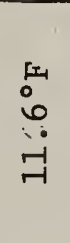 & $\begin{array}{l}\text { fr } \\
\text { in } \\
\text { - } \\
\text { न }\end{array}$ & 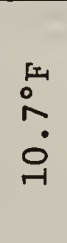 & $\begin{array}{l}\qquad x \\
0 \\
0 \\
-1 \\
-1\end{array}$ & $\begin{array}{l}\text { I } \\
0 \\
\infty \\
\dot{0} \\
0\end{array}$ & 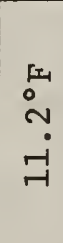 & $\begin{array}{l}\text { Ix } \\
\text { in } \\
\text { ? } \\
\text {-1 }\end{array}$ & $\begin{array}{l}\text { ris } \\
\text { in } \\
\text { in } \\
\text { न }\end{array}$ & 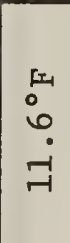 & $\begin{array}{l}0 \\
0 \\
\stackrel{0}{0} \\
\pi \\
-1 \\
0 \\
o 0 \\
0 \\
0\end{array}$ & $\stackrel{-}{\stackrel{-}{F}}$ \\
\hline 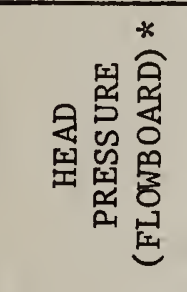 & 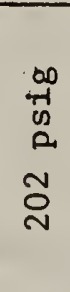 & 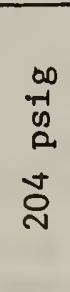 & $\begin{array}{l}\infty \\
\text { on } \\
0 \\
0 \\
m \\
0 \\
\text { N }\end{array}$ & $\begin{array}{l}\infty \\
\text {-1 } \\
0 \\
0 \\
0 \\
0 \\
\text { ஸे }\end{array}$ & 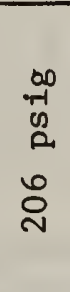 & $\begin{array}{l}\infty \\
-1 \\
0 \\
0 \\
0 \\
0 \\
\text { ก }\end{array}$ & 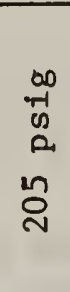 & 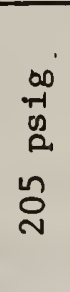 & 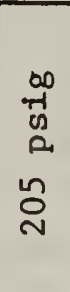 & 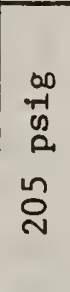 & 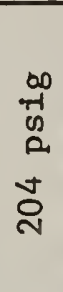 & $\begin{array}{l}\infty \\
01 \\
0 \\
0 \\
n \\
n \\
0 \\
N\end{array}$ & 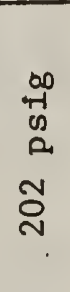 & $\begin{array}{l}\infty \\
-1 \\
0 \\
2 \\
0 \\
\sim \\
0 \\
\text { N }\end{array}$ & 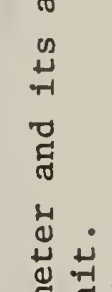 & 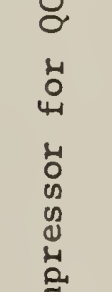 \\
\hline 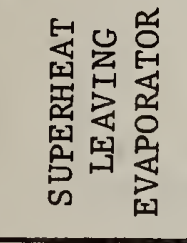 & $\begin{array}{l}x_{1} \\
\dot{0} \\
\dot{y} \\
\dot{y}\end{array}$ & 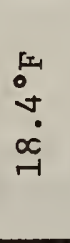 & $\begin{array}{l}\text { Lx } \\
\vdots \\
0 \\
0 \\
9 \\
-1\end{array}$ & 告 & 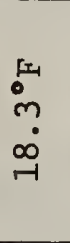 & 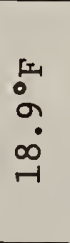 & 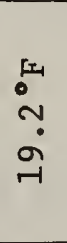 & $\begin{array}{l}\text { II } \\
\stackrel{0}{+} \\
\dot{0}\end{array}$ & $\begin{array}{l}\text { ix } \\
\text { in } \\
\text { a } \\
\text { - }\end{array}$ & $\begin{array}{l}\text { tr } \\
\text { in } \\
\text { a } \\
\text { ? }\end{array}$ & $\begin{array}{l}\text { [x } \\
\dot{0} \\
0 \\
\dot{0}\end{array}$ & $\begin{array}{l}\text { II } \\
0 \\
0 \\
0 \\
0 \\
i\end{array}$ & $\begin{array}{l}\mathfrak{x}_{1} \\
\stackrel{2}{*} \\
\stackrel{\mathrm{N}}{0}\end{array}$ & $\begin{array}{l}\text { rx } \\
\text { in } \\
\text { a }\end{array}$ & 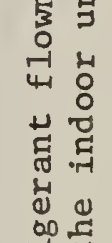 & 选 \\
\hline 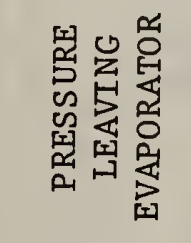 & 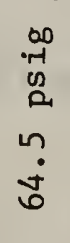 & 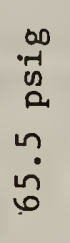 & $\begin{array}{l}\infty \\
1 \\
0 \\
0 \\
0 \\
0 \\
0 \\
0\end{array}$ & $\begin{array}{l}\infty \\
0-1 \\
0 \\
2 \\
0 \\
0 \\
0\end{array}$ & $\begin{array}{l}.00 \\
0 \\
0 \\
0 \\
0 \\
\dot{0} \\
0\end{array}$ & $\begin{array}{l}0 \\
0 \\
0 \\
0 \\
0 \\
0 \\
0 \\
0 \\
0\end{array}$ & 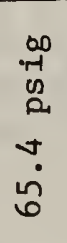 & $\begin{array}{l}0 \\
.7 \\
0 \\
0 \\
0 \\
0 \\
0 \\
0\end{array}$ & $\begin{array}{l}\infty \\
\text { n- } \\
0 \\
0 \\
0 \\
-1 \\
\text { ñ } \\
0\end{array}$ & $\begin{array}{l}\text { a } \\
.7-1 \\
0 \\
0 \\
0 \\
0 \\
0 \\
0\end{array}$ & $\begin{array}{l}00 \\
\text { o- } \\
0 \\
0 \\
0 \\
0 \\
0 \\
0\end{array}$ & $\begin{array}{l}0 \\
0 \\
0 \\
0 \\
0 \\
0 \\
0 \\
0 \\
0\end{array}$ & $\begin{array}{l}\infty \\
-1 \\
0 \\
0 \\
0 \\
0 \\
0 \\
0\end{array}$ & 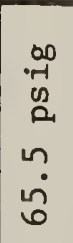 & 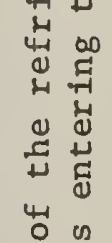 & 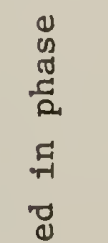 \\
\hline 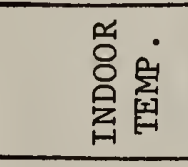 & $\begin{array}{l}51 \\
0 \\
+1 \\
0 \\
0 \\
\end{array}$ & $\begin{array}{l}5 \\
0 \\
\sigma \\
0 \\
0\end{array}$ & $\begin{array}{l}\qquad x \\
0 \\
0 \\
0 \\
0 \\
\end{array}$ & $\begin{array}{l}5 \\
0 \\
\infty \\
0 \\
0 \\
1 \\
\end{array}$ & 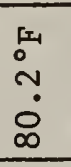 & $\begin{array}{l}5 \\
0 \\
0 \\
0 \\
0 \\
0\end{array}$ & $\begin{array}{l}5 \\
0 \\
\text { ? } \\
0 \\
1\end{array}$ & $\begin{array}{l}r \\
0 \\
i \\
0 \\
i \\
\end{array}$ & $\begin{array}{l}x_{1} \\
0 \\
\infty \\
0 \\
0 \\
\end{array}$ & $\begin{array}{l}{[} \\
0 \\
\infty \\
0 \\
i \\
\end{array}$ & 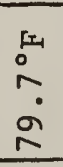 & $\begin{array}{l}\text { 5x } \\
\text { in } \\
\text { in } \\
\text { a }\end{array}$ & $\begin{array}{l}\text { L1 } \\
\stackrel{2}{*} \\
0 \\
0 \\
\end{array}$ & $\begin{array}{l}x_{1} \\
\stackrel{1}{N} \\
\stackrel{0}{\infty} \\
\infty\end{array}$ & $\begin{array}{l}0 \\
0 \\
0 \\
0 \\
0 \\
0 \\
0 \\
0 \\
0 \\
0\end{array}$ & 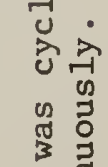 \\
\hline 里 & $\begin{array}{l}\text { L1 } \\
\text { in } \\
\text { in } \\
\text { D }\end{array}$ & \begin{tabular}{l} 
Lx \\
$\circ$ \\
\multirow{2}{*}{} \\
$\infty$ \\
$\infty$
\end{tabular} & $\begin{array}{l}\stackrel{5}{1} \\
\vdots \\
0 \\
\dot{N} \\
\infty\end{array}$ & $\begin{array}{l}\stackrel{1}{1} \\
\vdots \\
\dot{v} \\
\dot{0}\end{array}$ & $\begin{array}{l}\stackrel{1}{1} \\
0 \\
\sim \\
\sim \\
\infty\end{array}$ & 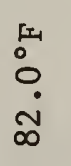 & 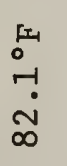 & $\begin{array}{l}\qquad x \\
0 \\
\dot{v} \\
\dot{N} \\
\infty\end{array}$ & $\begin{array}{l}\stackrel{\not 1}{0} \\
\stackrel{-}{-} \\
\dot{N} \\
\infty\end{array}$ & $\begin{array}{l}{[x} \\
\circ \\
0 \\
\dot{0} \\
\infty\end{array}$ & 留 & 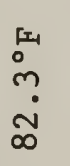 & $\begin{array}{l}L_{1} \\
0 \\
0 \\
0 \\
\infty \\
\infty\end{array}$ & $\begin{array}{l}{[1} \\
0 \\
\infty \\
\dot{0} \\
\infty\end{array}$ & 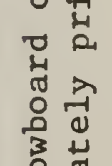 & 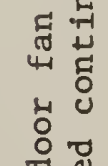 \\
\hline 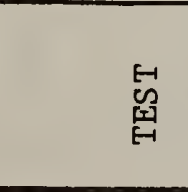 & $\frac{m}{\stackrel{m}{0}}$ & $\stackrel{n}{0}$ & $\begin{array}{l}0 \\
\dddot{O} \\
0\end{array}$ & $\stackrel{n}{0}$ & $\stackrel{\infty}{\dddot{0}}$ & $\begin{array}{l}\text { of } \\
\text { o }\end{array}$ & $\frac{-1}{=}$ & $\begin{array}{l}\frac{*}{*} \\
\stackrel{*}{-1} \\
\stackrel{-1}{*} \\
0 \\
0\end{array}$ & 严 & $\begin{array}{l}\tilde{y} \\
0 \\
0\end{array}$ & $\begin{array}{l}\infty \\
\stackrel{1}{=} \\
0 \\
0\end{array}$ & $\begin{array}{l}\text { ô } \\
\text { ț } \\
y\end{array}$ & $\frac{\stackrel{\circ}{N}}{\stackrel{0}{*}}$ & $\begin{array}{l}\stackrel{-1}{N} \\
0 \\
0\end{array}$ & 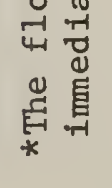 & 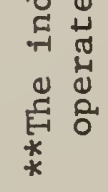 \\
\hline
\end{tabular}




\begin{tabular}{|l|c|c|c|c|c|}
\hline TEST & $\begin{array}{c}\text { STEADY-STATE } \\
\text { EER }\end{array}$ & $\begin{array}{c}\text { CYCLIC } \\
\text { EER }\end{array}$ & $\begin{array}{c}\text { CYCLIC } \\
\text { CLF }\end{array}$ & $\begin{array}{c}\text { CY CLIC } \\
\text { PLF }\end{array}$ & $\begin{array}{c}\text { CYCLIC } \\
\text { CD }\end{array}$ \\
\hline QC $\# 7$ & 7.46 & 4.98 & .125 & .668 & .38 \\
\hline QC $\# 8$ & 7.46 & 5.06 & .126 & .678 & .37 \\
\hline QC $\# 9$ & 7.42 & 5.09 & .130 & .686 & .36 \\
\hline QC $\# 10$ & 7.34 & 5.00 & .127 & .681 & .37 \\
\hline QC $\# 11 *$ & 7.28 & 5.37 & .136 & .737 & .30 \\
\hline QC $\# 16$ & 7.36 & 5.12 & .129 & .696 & .35 \\
\hline QC $\# 17$ & 7.18 & 5.09 & .132 & .708 & .34 \\
\hline QC $\# 18$ & 7.29 & 5.23 & .133 & .717 & .33 \\
\hline QC $\# 19$ & 7.30 & 5.25 & .135 & .720 & .32 \\
\hline QC $\# 20$ & 7.39 & 5.33 & .135 & .721 & .32 \\
\hline QC $\# 21$ & 7.48 & 5.18 & .130 & .692 & .35 \\
\hline
\end{tabular}

*The indoor fan was cycled in phase with the compressor for Test QC \#11. For all other tests the indoor fan operated continuously.

NOTE: The variation in cyclic data for this test series is somewhat greater than that which would exist if performed in strict accordance with [3] and [4] because of charge variability and because of the varying point data intervals which were selected for other testing considerations. 


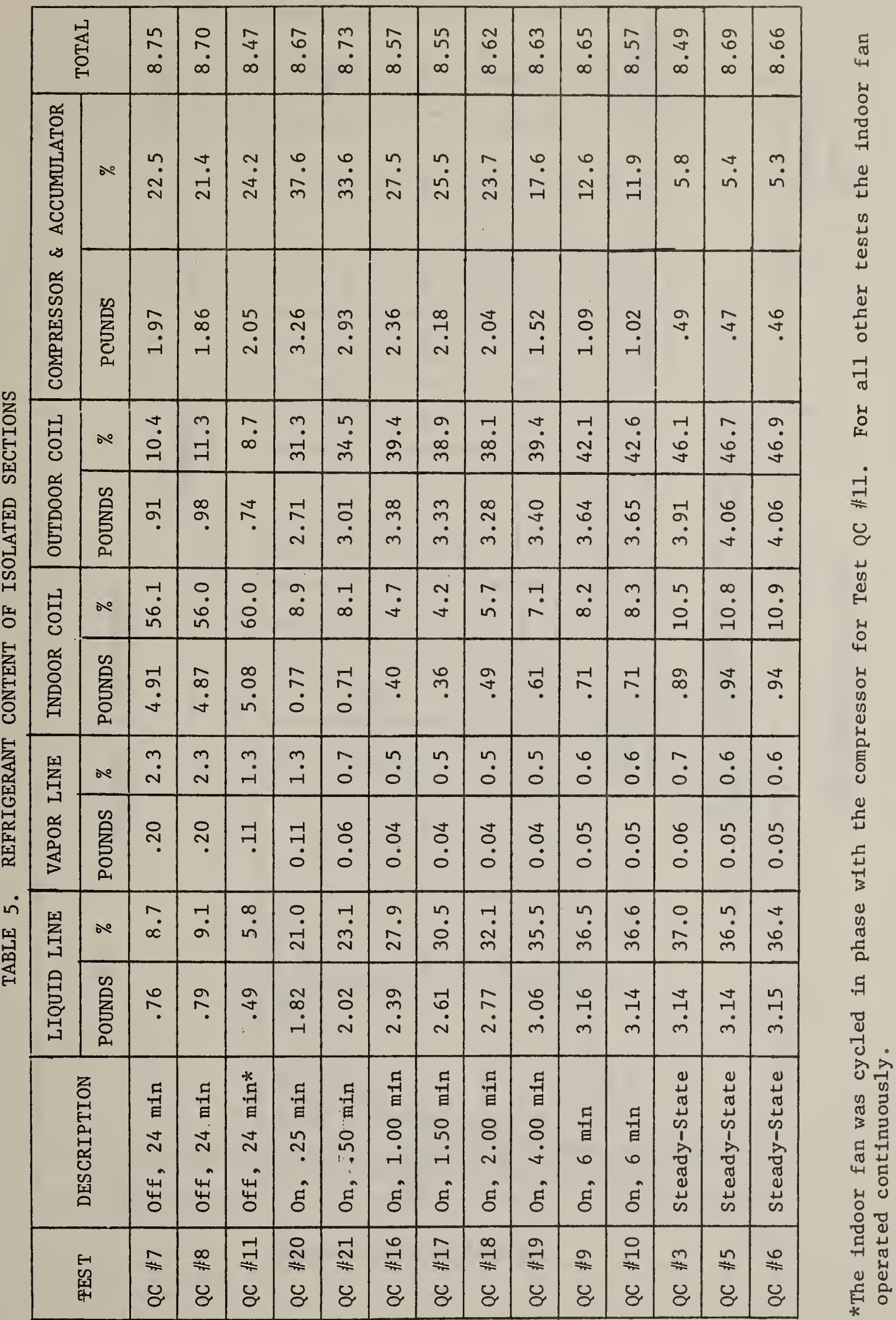




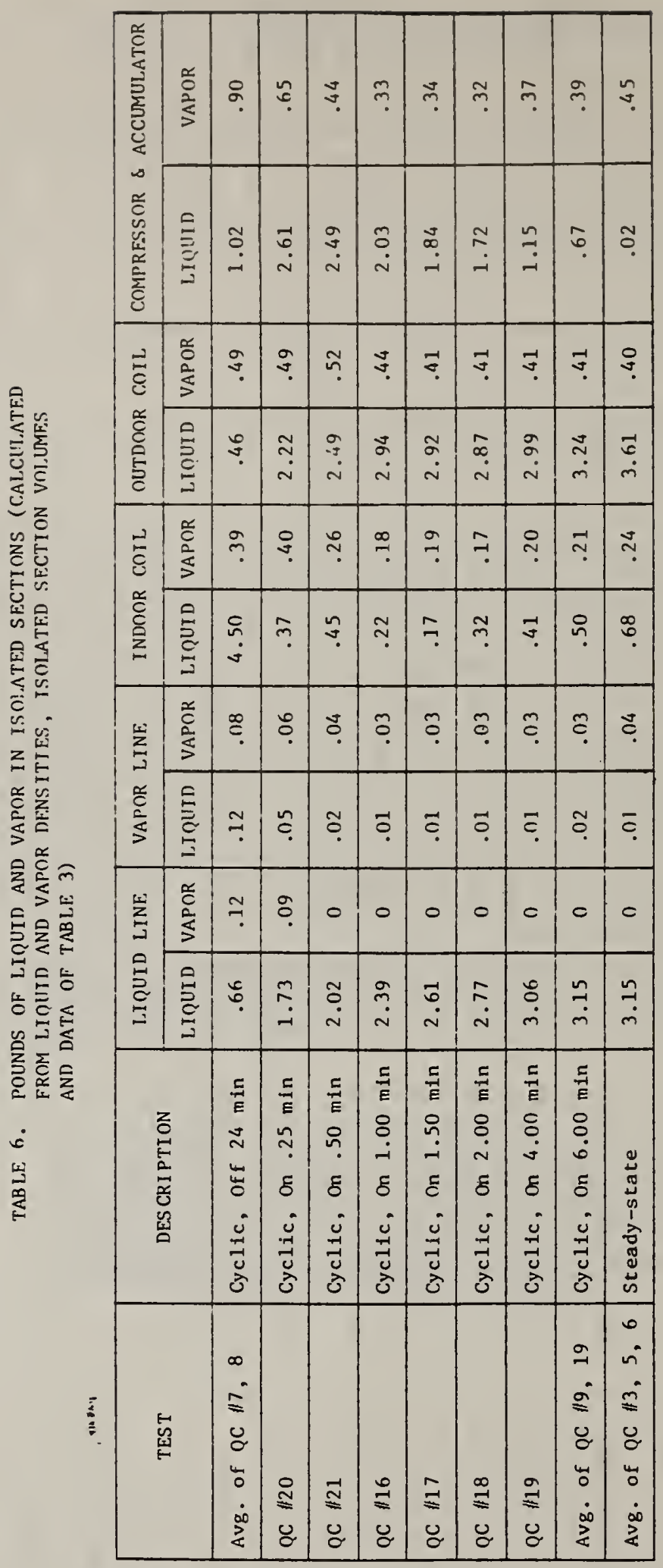




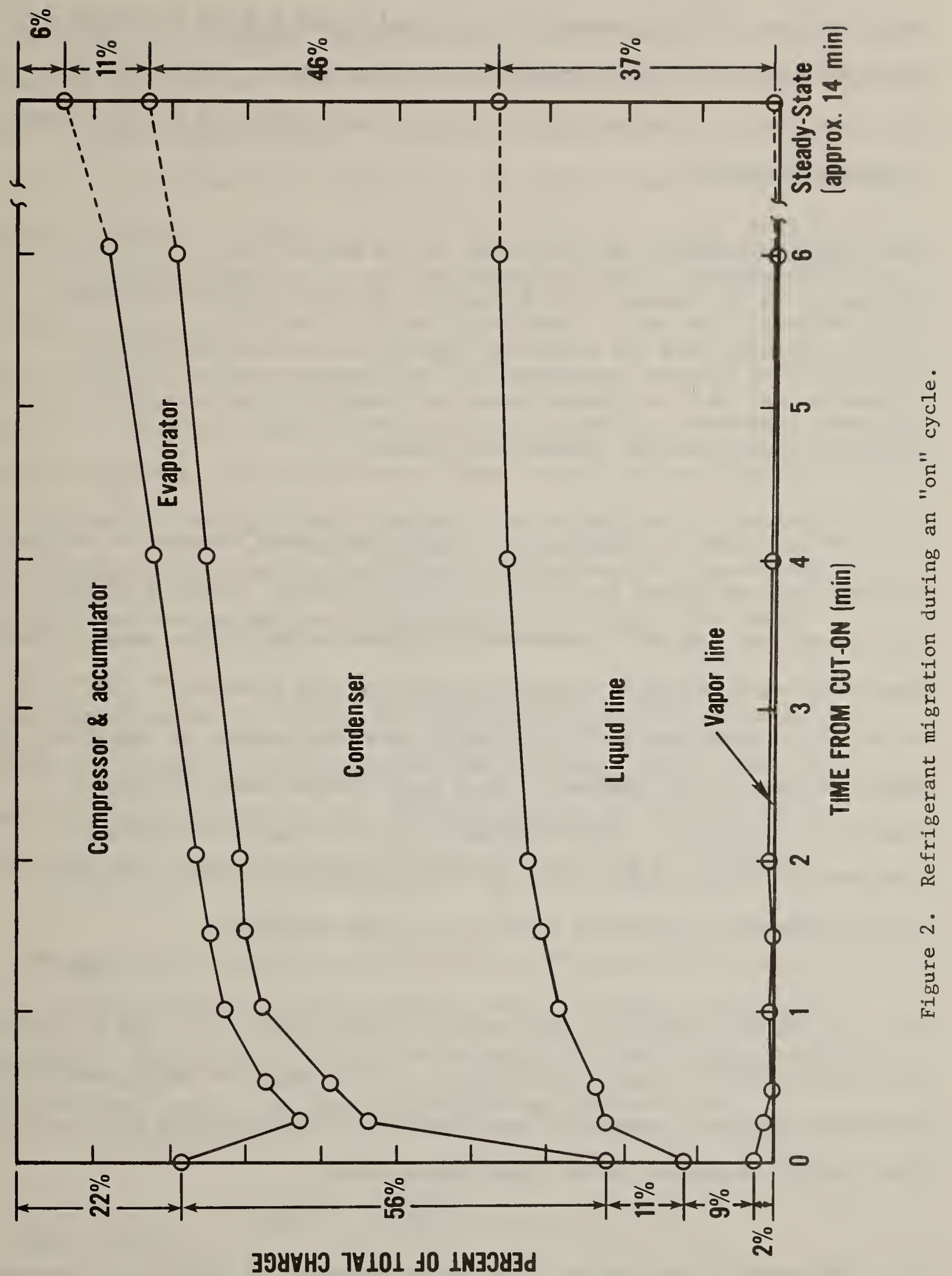


was consistent with the presence of saturated liquid and the top temperature was indicative of the high temperature in the compressor compartment indicating that this liquid refrigerant could not have been transferred to the accumulator by thermal gradients.

Some liquid refrigerant was also found in the suction line at the end of the off-cycle. It is presumed that during the off-cycle, liquid refrigerant flowed by gravity from the evaporator through the suction line to the accumulator and that refrigerant vapor was transferred in the opposite direction by the existing temperature gradient.

There was no evidence of substantial liquid refrigerant transfer to the compressor crankcase during the off-cycle or on start-up. During a typical cyclic test, an insulated thermocouple soldered to the bottom corner of the compressor shell indicated a steady temperature rise from $65.0^{\circ} \mathrm{C}\left(149^{\circ} \mathrm{F}\right)$ at cut-on to a temperature of $76.1^{\circ} \mathrm{C}\left(169^{\circ} \mathrm{F}\right)$ after six minutes of operation. A sharp decrease in the temperature would have occurred had there been a significant quantity of liquid refrigerant in the compressor crankcase. Consequently, it was assumed that all the refrigerant in the liquid phase in the compressor-accumulator section was in the accumulator.

3) Most of the refrigerant that was in the evaporator at the end of the "off" cycle left within 15 seconds after start-up. The amount of refrigerant in the evaporator reached a minimum at approximately 1.5 minutes after start-up and then steadily increased to its steady-state value.

4) The amount of refrigerant in both the condenser and liquid line increased steadily from their start-up to their steady-state values. 
5) The amount of refrigerant in the compressor and accumulator section reached its maximum recorded amount of refrigerant ( $38 \%$ of the total charge) at the data point 15 seconds after start-up. The amount of refrigerant in this section slowly decreased to its steady-state value ( $5 \%$ of the total charge) as the accumulator gradually returned its liquid refrigerant to circulation. Clearly much of the cyclic loss can be attributed to the unit being in effect "undercharged" while the liquid refrigerant is stored in the accumulator. This point is emphasized in figure 3 in which the unit capacity and the temperature measured by a thermocouple soldered to the bottom corner of the accumulator minus the compressor saturated suction temperature are plotted against time. Here it is seen that the capacity does not reach its steady-state value until the accumulator bottom temperature departs substantially from the compressor saturated suction temperature, an indication that the accumulator has been emptied of liquid refrigerant.

Further comparison of the refrigerant migration data to unit performance requires calculation of the refrigerant side capacity. Fig. 4 shows the measured air side capacity for the first six minutes of operation and a refrigerant side capacity which was calculated from this air side data.

The refrigerant side capacity was calculated by drawing a smooth curve through the air side data points and then assuming that, for small time intervals (0.1 minute), the air side capacity was exponentially approaching a constant refrigerant side value. Expressed as an equation this would be:

$$
\dot{Q}_{R E F}=\dot{Q}_{A I R}\left(t_{1}\right)+\frac{\dot{Q}_{A I R}\left(t_{2}\right)-\dot{Q}_{A I R}\left(t_{1}\right)}{1-\exp \left(\frac{t_{1}-t_{2}}{\tau}\right)}
$$




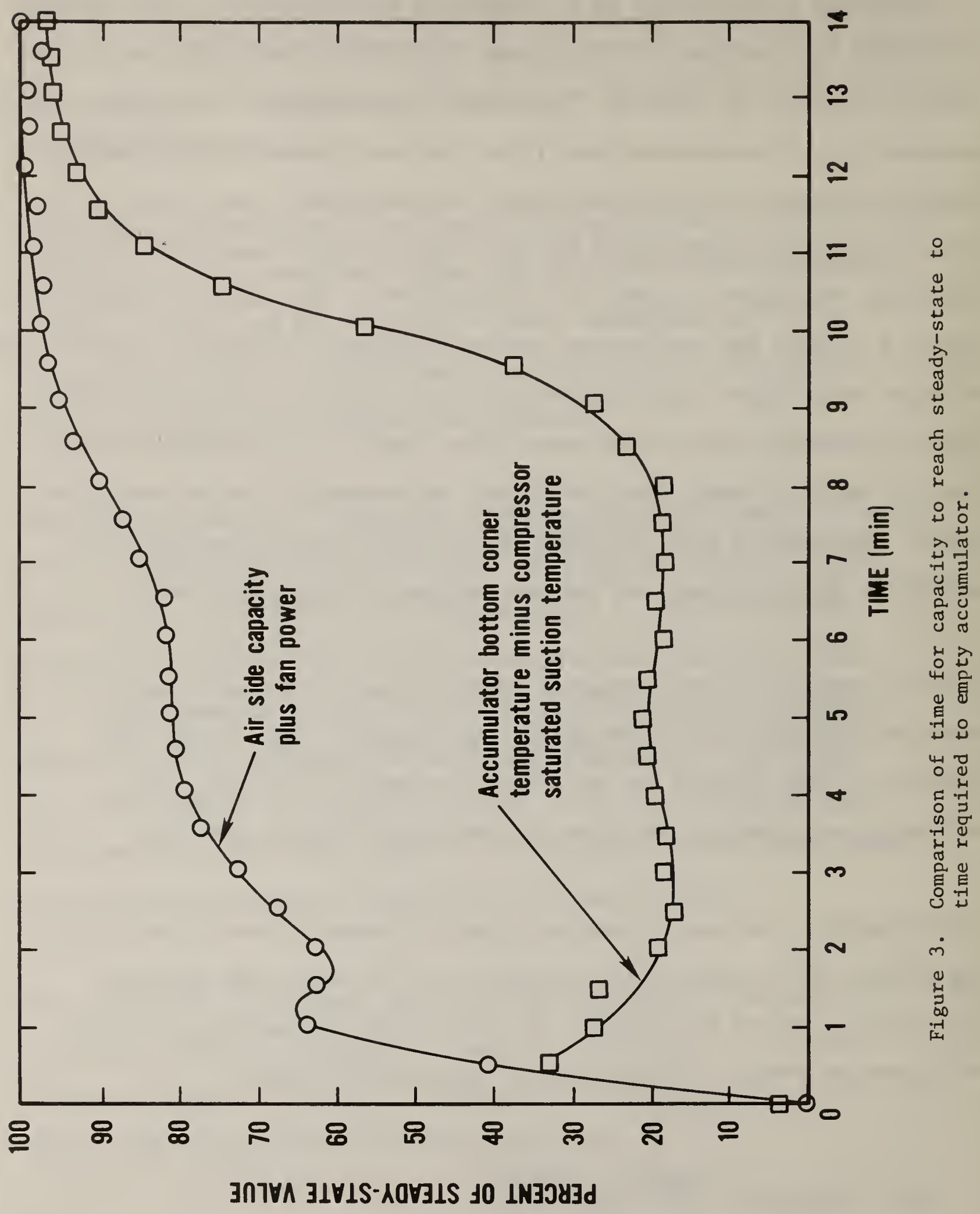




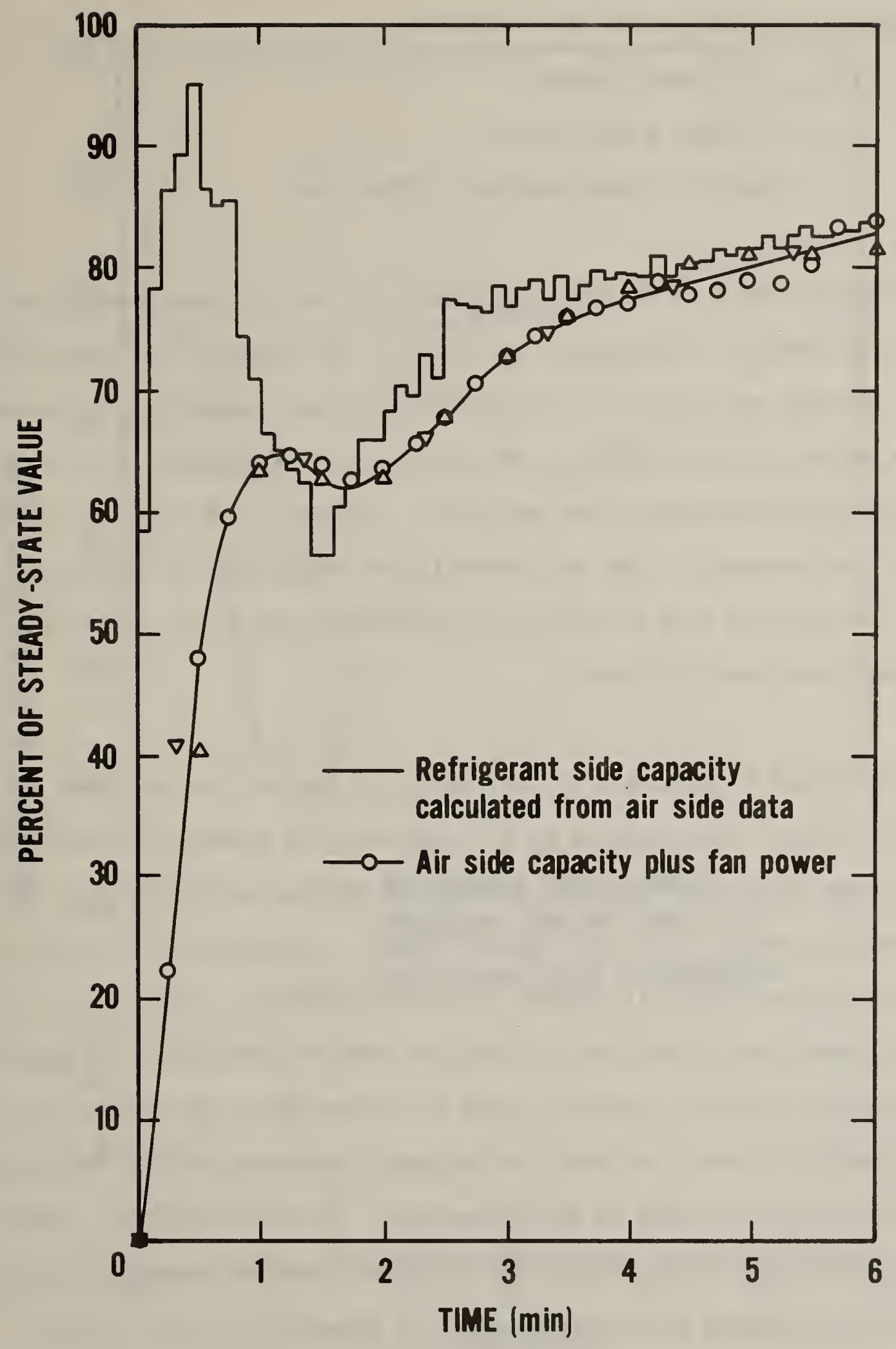

Figure 4. Comparison of Transient air-side capacity to coincident transient refrigerant side capacity. 


$$
\text { where } \begin{aligned}
& \dot{Q}_{\mathrm{REF}}=\text { refrigerant side capacity } \\
& \dot{\mathrm{Q}}_{\mathrm{AIR}}=\text { air side capacity } \\
& \mathrm{t}_{1}, \mathrm{t}_{2}=\text { times } 1 \text { and } 2 \text {, min. } \\
& \tau=\text { evaporator time constant, MC/UA, min. }
\end{aligned}
$$

The evaporator time constant was calculated from the coil mass data given in Table 2 and from the steady-state test value of UA (equal to the steady-state capacity divided by the air to refrigerant saturation temperature difference) giving a value of 0.63 minutes for the evaporator time constant. In figure 5 this calculated refrigerant side capacity is compared to the mass of refrigerant in the evaporator. The two curves follow one another in shape quite well after 15 seconds and lead to the following interpretation for the shape of the refrigerant side capacity curve.

These results may be explained by considering at cut-on, that there is a sufficient amount of refrigerant in the evaporator to allow near steady-state capacity even though the capillary tube is not feeding sufficiently to sustain this capacity level. As the refrigerant leaves the evaporator by nucleate boiling and slug flow, liquid is carried into the accumulator. This drops capacity to a level that can be sustained by the flow that the capillary will permit. This "capillary-1imiting" capacity value is reduced below the steady-state value primarily because the unit is effectively "undercharged" by the amount of liquid temporarily lying in the accumulator. As the accumulator returns its retained liquid to the system, the condenser pressure increases causing the capillary flowrate to increase toward its steady-state value. This phenomena is further complicated by the lack of stable liquid seal ahead of the capillary during this period. 


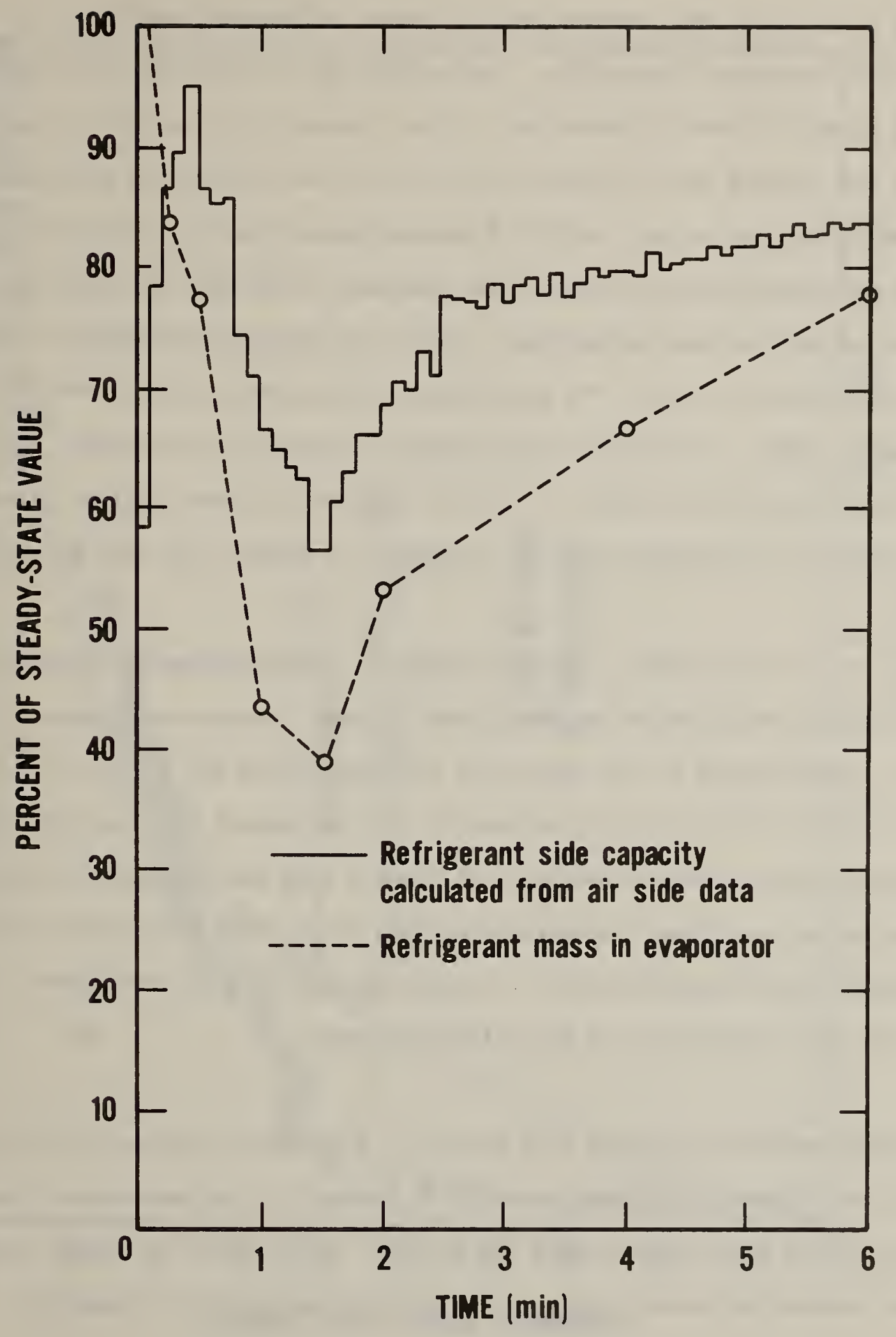

Figure 5. Comparison of refrigerant side capacity to refrigerant mass in evaporator. 
The unit sight glass was observed during several cycles and found to be $1 / 2$ full after 30 seconds of operation. The outlet port of the sight glass was $3 / 4$ full after 1 minute of operation. After 1 minute and 45 seconds, the outlet port was covered but the bubble in the top of the sight glass ocaasionally connected to the outlet port until 4.5 minutes after start up. This indicated that total liquid stability between the condenser outlet and the capillary tube entrance had not yet been established. The sight glass was completely clear 5.5 minutes after start-up. The pseudo-high refrigerant capacity noted in the first minute then, is a result of the excess of evaporator refrigerant accumu-! lated during the off-cycle and, as this is "pumped" out, the capillary feed tends to starve the evaporator until, gradually, a steady flow rate is achieved.

The two sets of test results, shown in figure 6, were obtained by allowing the unit to come to steady-state capacity after several 6 minute-on/24 minute-off cycles. They differed in the indoor air dew point which was $37.0^{\circ} \mathrm{F}\left(2.8^{\circ} \mathrm{C}\right)$ for Test QC 26 and $20.5^{\circ} \mathrm{F}\left(-6.4^{\circ} \mathrm{C}\right)$ for Test QC 27 . The second test (at the lower dew point) was pe-formed to determine if, when a very low saturation temperature occurred during the starved evaporator period, there would be a significant intra-cycle latent dooling effect. It was concluded from the closeness of these two curves that this was not a significant concern.

The insight provided by figure 5 is useful in preparing a regressive fit to the capacity as a function of time presented in figure 6 . The experimental data shown in figure 6 were fitted with two curves. In the first, a single time constant exponential curve, $\dot{Q} / \dot{Q}_{s s}=\left(1-e^{-\tau / \tau 1}\right)$, where $\tau 1+3.0$ minutes, is 


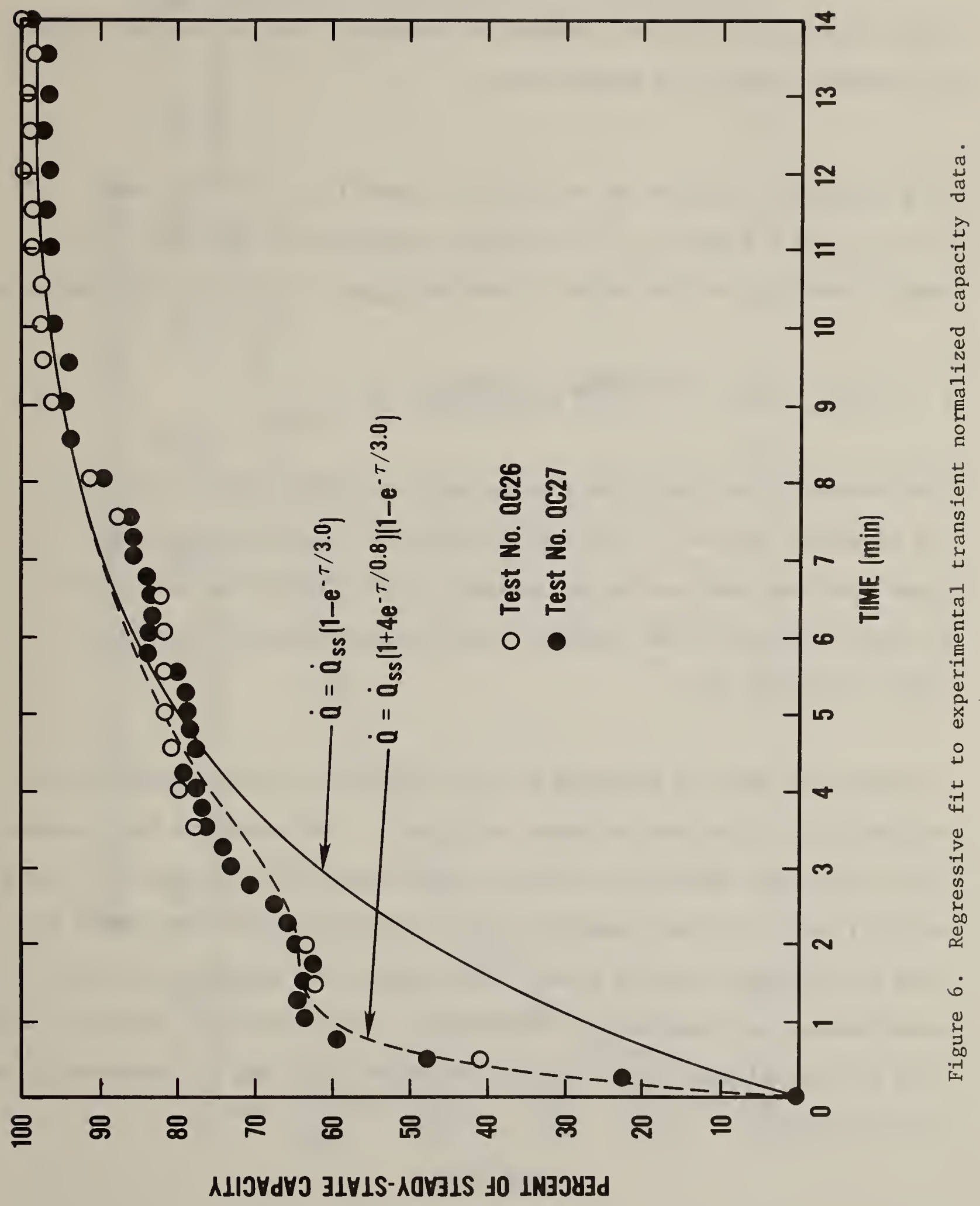


satisfies the 0 and infinity time conditions and matches the transient data values fairly well after four minutes of operation. However, before that time the indicated capacity is much too low.

If a second time constant in the form of a term $\left(1+a e^{-t / \tau 2}\right)$, where $a=4.0, \tau 2=0.8$ minutes, is introduced to simulate the very high, but rapidly decaying, initial capacity shown in figure 5 , the resulting equation is

$$
\dot{Q}=\dot{Q}_{s s}=\left(1-e^{-\tau / \tau 1}\right)\left(1+a e^{-\tau / \tau}\right)
$$

This equation form, when fitted to the data, provides a very good trace of the phenomena observed. It should be noted that the terms, $\tau 1$ and $\tau 2$, in these equations have now become regressive curve fitting constants and are not time constants in the classical transient heat-transfer capacitance sense of equation 5.1 .

An additional test was performed to record the capacity decay after shut-down. The results of this test are shown in figure 7 . The regressive least squares fit to this data resulted in the shown time constant of 0.61 minutes. During this off-cycle it is not surprising that a simple decay function should simulate the transient capacity so well since none of the accumulator or capillary complications are significant. Furthermore, it is interesting to note that for this air-conditioning unit a similar coefficient value may be construed for the start-up period. 


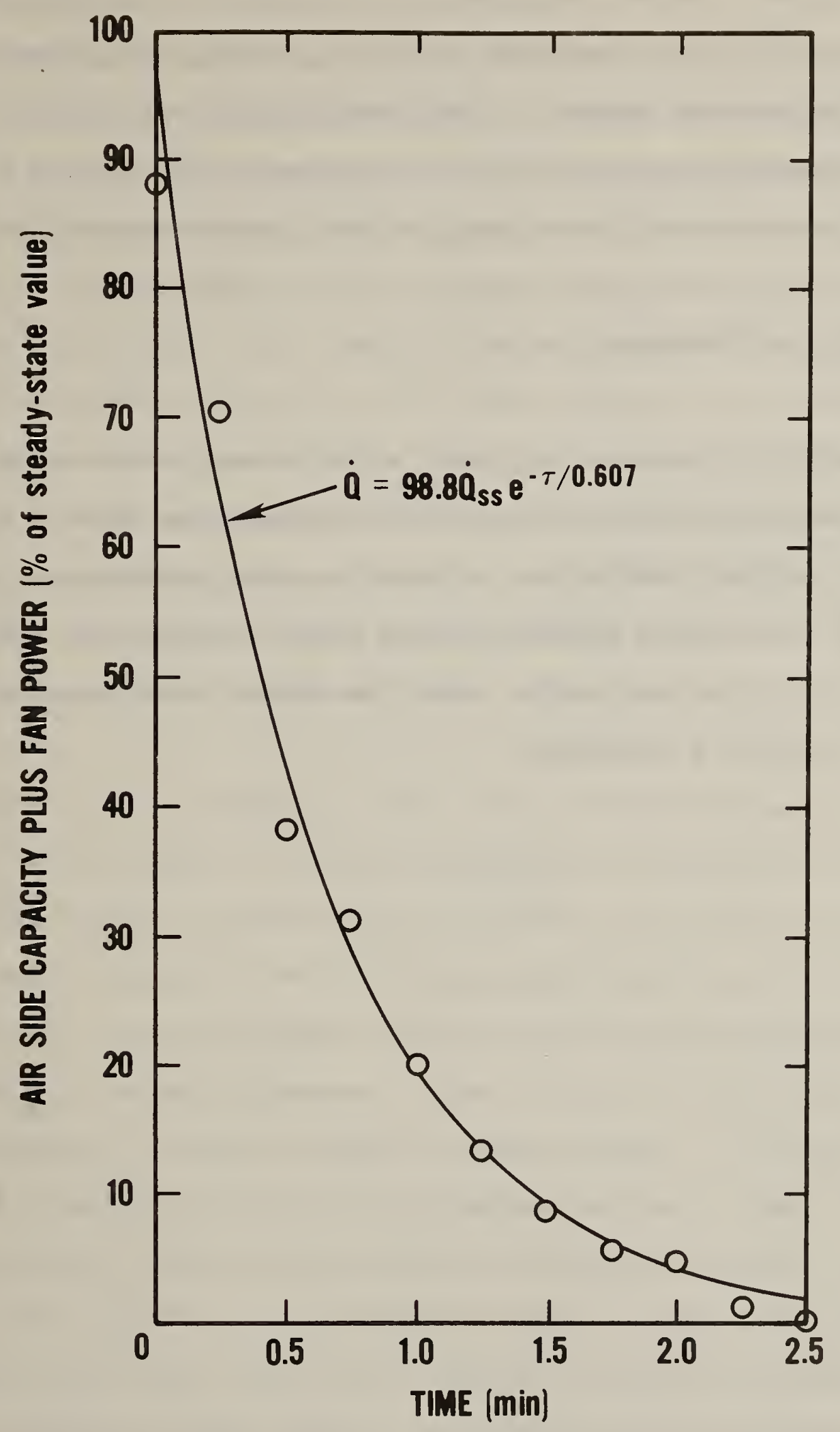

Figure 7. Capacity decay after compressor shut-off with continuous fan operation 
As shown in figure 4, the unit refrigerant side capacity for the first $3 / 4$ minute of operation is near the steady-state value. Making the assumption of constant refrigerant-side capacity for the first $3 / 4$ minute of operation, a regressive exponential least-squares fit of the form $y=a e^{b x}$ was made to the experimental air-side data by rearranging the unit air-dide capacity to the form:

$$
1-\dot{Q}_{\dot{Q}_{s s}}=a e^{b x} \text {, where } b=-1 / \tau \text {. }
$$

The results of this fit were $a=0.99$ and $\tau=0.80$ minutes. The value of $\tau$ is reasonably close to the value of 0.63 minutes calculated from the coil mass, specific heat, and heat transfer rate. A somewhat higher experimental time constant could be attributed to additional system masses in addition to the evaporator and to the measurement system. This time constant being equal to $\tau 2$ in equation 5.2 is purely a coincidence. 


\section{CONCLUS IONS}

The empirical results of this study suggest that it is possible to simulate the dynamic operation of an air conditioner on two levels of complexity. The first level, a single time constant characterizing the start-up and shut down operation, tends to ignore some of the actual physical phenomena that occur, however, as an approximation or a next step past steady-state towards reality this may be adequate. Such an approach may be considered when the model is for characterizing a "typical" or the "general class" of air conditioners. Unfortunately a time constant value that is the best representative of the state of the art is not possible to determine without considerable further study of many different units. The value obtained for this unit is undoubtedly a typical value but how wide the range or what the median is for the air conditioning units of today is not known.

The second level of simulation is that which is of the form shown in equation 5.2. Here both facets of the cyclic degradation are accounted for and such a form could be used to characterize the operation of any given air conditioner. This level of simulation and its respective empirical data are essential if the intention of the simulation is to distinguish among individual units' characteristics or dynamic performance. That is to say, if proper credit is to be attributed to a specific design for rating purposes. If the air side capacity of a specific unit were to be determined, as shown in Fig. 4, from a continuous plot of the air side thermopile temperature difference, that air conditioner's dynamic performance would probably be simulated as accurately as is done by the current cyclic tests. However, between the pre-measurement operations required to assure periodic repeatability and the confirming shut down 
dynamic measurements, the experimental burden is no less than the existing cyclic tests. It would therefore appear that the best hope for a less burdensome characterization of a given unit's dynamic performance is through sufficient study of the individual components' interaction and impact on refrigerant migration and then an establishment of a series of enhancement (positive or negative) factors which could be attributed to a given unit's steady-state performance depending on its particular design. 


\section{REFERENCES}

1. Chi, J. and Didion, D., "A Simulation Model of the Transient Performance of a Heat Pump", International Journal of Refrigeration, Volume 5, Number 3, (International Institute of Refrigeration, Paris, France, May 1982).

2. Nguyen, H., Goldschmidt, V. W. and Tree, D. R., "Analysis of the DoE Test Procedures", Publication No. HL 81-11 (Ray W. Herrick Laboratories, Purdue Unqversity, West Lafayette, Indiana 47907, March 1981).

3. Kelly, G. E. and Parken, W. H., "Method of Testing, Rating and Estimating the Seasonal Performance of Central Air Conditioners and Heat Pumps Operating in the Cooling Mode", NBSIR 77-1271, (National Bureau of Standards, Washington, D.C. 20234, April 1978).

4. "Methods of Testing for Seasonal Efficiency of Unitary Air-Conditioners and Heat Pumps", ASHRAE Standard 116-83, (American Society of Heating, Refrigerating and Air Conditioning Engineers, Atlanta, Georgia 30329, 1983).

5. Parken, W. H., Beausoliel, R. W., and Kelly, G. E., "Factors Affecting the Performance of a Residential Air-to-Air Heat Pump", ASHRAE Transactions, Vo1. 83, Part 1, (American Society of Heating, Refrigerating, and Air Conditioning Engineers, Atlanta, Georgia 30329, 1977).

6. "Methods of Testing for Rating Unitary Air Conditioning and Heat Pump Equipment", ASHRAE Standard 37-69, (American Society of Heating, Refrigerating, and Air Conditioning Engineers, Atlanta, Georgia 30329, 1969). 
APPENDIX A - COMPARISON OF CYCLIC PERFORMANCE TO REDUCED CHARGE STEADY-STATE PERFORMANCE

In an attempt to verify the "starved evaporator" concept suggested, several steady-state tests were performed with the refrigerant charge reduced for comparison to the transient data taken during the period in which liquid trapped in the accumulator was believed to be the major cause of cyclic loss. This data is shown in figure Al and capacities calculated from the indicated linear least squares fit to the capacity data in figure Al are compared to the transient capacity from figure 4 in figure A2. The capacity from 1.5 minutes after start-up until 6 minutes after start-up exceeds the value calculated from the transient data by approximately $10 \%$. The air side capacity which is equivalent to the refrigerant side capacity calculated from the accumulator contents and reduced charge steady-state capacity as shown in figure A2 is compared to the experimental air side capacity in figure A3. 


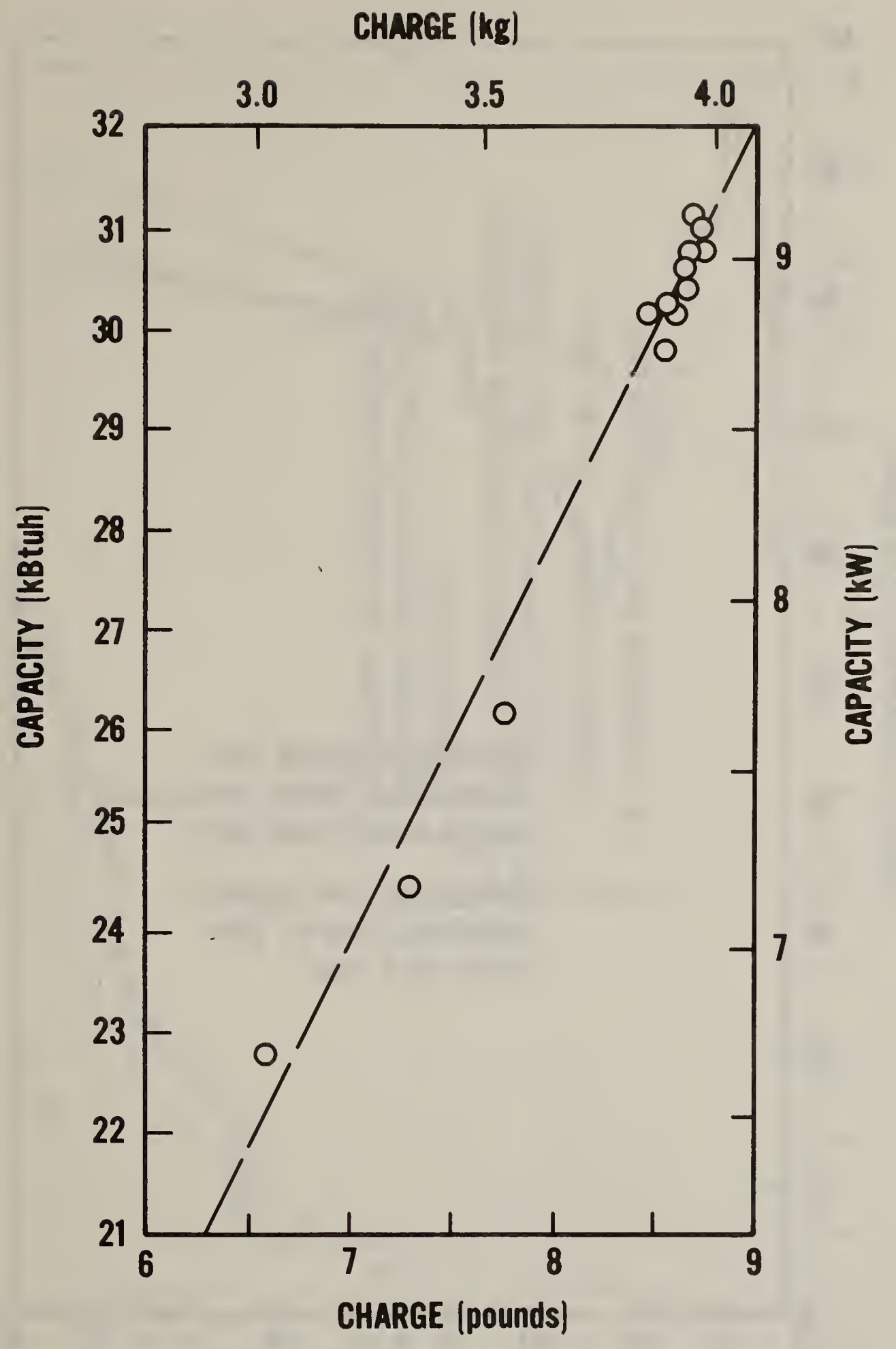

Figure A1. Unit capacity as a function of charge. 


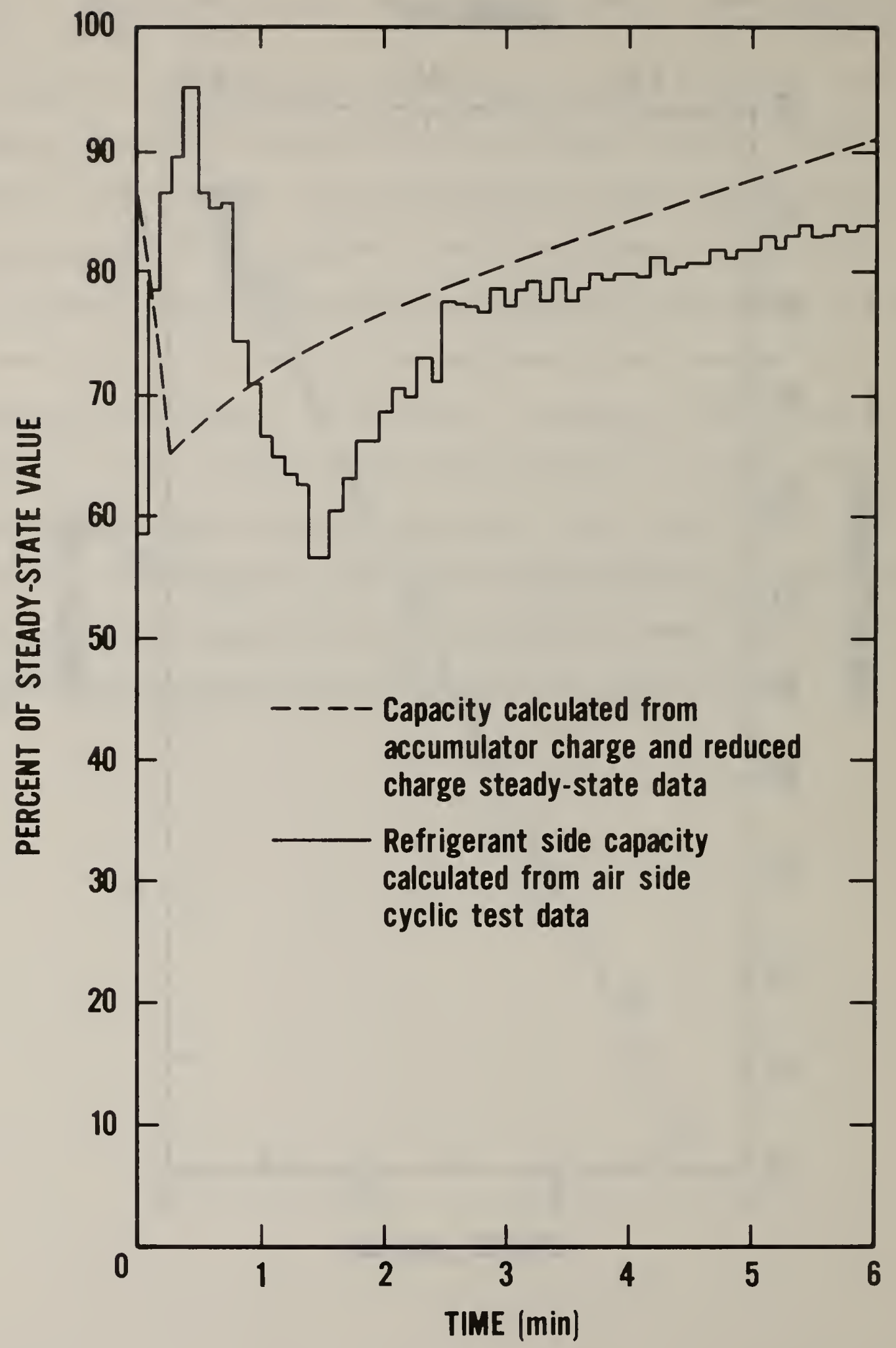

Figure A2. Comparison of refrigerant side capacity to capacity calculated from accumulator content and reduced charge steady-state data. 


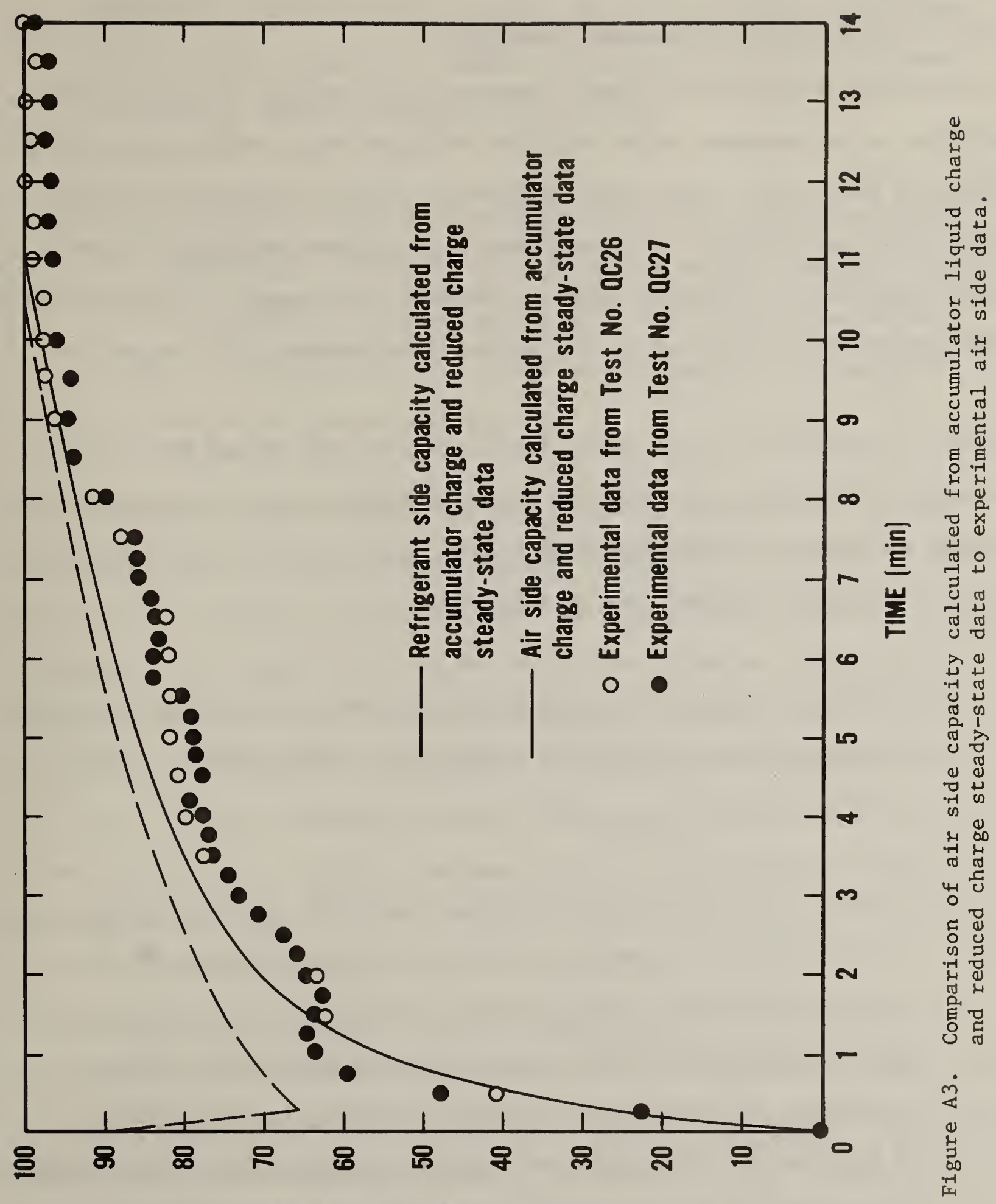

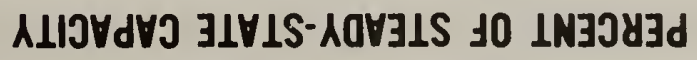




\section{APPENDIX B}

\section{REFRIGERANT MIGRATION MEASUREMENT TECHNIQUES}

This appendix describes unsuccessful measurement techniques which were tried in addition to the pneumatic valve isolation technique which produced the data discussed in this report. With additional effort it may be possible to surmount the difficulties which are described below. This effort would be worthwhile as these unsuccessful measurement methods (weighing and accumulator surface temperature measurement) both produce data without interruption of unit operation.

Prior to installation of the pneumatically operated ball valves for isolation of system components, a considerable amount of effort was put into attempts to measure refrigerant migration by weighing the outdoor unit. These attempts failed for several reasons, some of which are:

1) Stiffness of the suction and discharge lines - this reduced the scale sensitivity and, if the unit rocked on the scale, produced a zero shift.

2) Flexure of the suction and discharge lines with pressure--as the unit cycled the discharge pressure varied from approximately 220 psia to 160 psia and the suction pressure from 65 psia to 160 psia. These fluctuations in the lines resulted in forces being transmitted to the scales upon which the unit rested of approximately \pm 0.5 pounds. This effect was studied by pressurizing the unit with helium and was found to depend on the initial force the lines exerted 
on the unit (i.e., how they were supported) and to have poor repeatability. It is presumed that there was also an effect on line force due to cyclic temperature changes of the lines, however, no attempt was made to verify or measure such an effect.

3) The refrigerant weight is a small percentage of the total weight of the outdoor unit. Typically the refrigerant weight to measured would be on the order of 4 pounds and the unit weight 160 pounds $(4 / 160=$ 2.5\%). A small error in unit weight would result in a large error in presumed refrigerant weight.

After a continuing lack of success with weighing the outdoor unit, the ball valves were installed which produced the data discussed in this report. The ball valve data indicated substantial "off" cycle refrigerant migration to the accumulator. This migration to the accumulator was important in evaluating the sources of cyclic loss. Since the accumulator is normally part of the outdoor unit along with the compressor and the condenser, weighing the outdoor unit, since it cannot distinguish between refrigerant contained in the condenser as opposed to that in the accumulator, would not have provided adequate data for this analysis.

An attempt was made to determine the refrigerant content of the accumulator by monitoring insulated thermocouples soldered to the accumulator and spaced $25 \mathrm{~mm}$ (one inch) apart up its side from bottom to top. These indicated a refrigerant content in the accumulator approximately $50 \%$ greater than that measured with the quick closing valves. The possible reasons for this are turbulence of the refrigerant in the accumulator as a result of boiling and depression and perturbation of the refrigerant surface caused by the high velocity of the entering refrigerant vapor. 
NBS-114A (REV. $2 \rightarrow C$ )

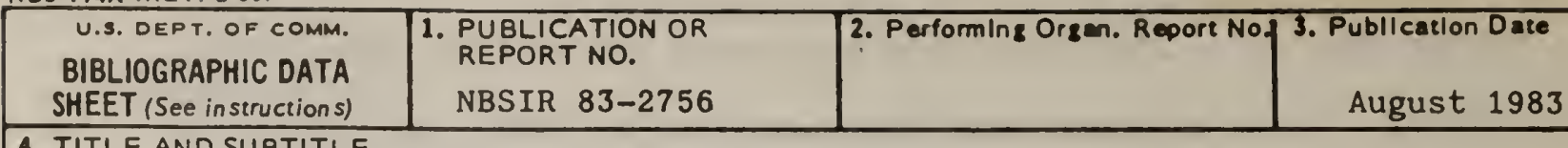

4. TITLE AND SUBTITLE

A Laboratory Investigation of Refrigerant Migration in a Spl1t Unit Air Conditioner

5. $\operatorname{AUTHOR}(S)$

William J. Mulroy and David A. Didion

6. PERFORMING ORGANIZATION (If joint or other than NBS, see Instructions)

NATIONAL BUREAU OF STANDARDS

DEPARTMENT OF COMMERCE

WASHINGTON, D.C. 20234

9. SPONSORING ORGAWIZATION NAME AND COMPLETE ADDRESS \{Street, CTY, Stote, ZIP\}

U.S. Department of Energy

Office of Conservation and Renewable Energy

1000 Independence Avenue, S.W.

Washington, D.C. 20585

10. SUPPLEMENTARY NOTES

Document describes a computer program; SF-185, FIPS Software Summary, is attached.

11. ABSTRACT (A 200-word or less factual summary of most significant information. If document includes a s/gniflcant bibliography or literature survey. mention it here)

The relationship between cyclic refrigerant migration and cyclic loss for a residential, split-system air conditioner has been investigated. The cyclic refrigerant migration was measured at different points in the operating cycle by simultaneously shutting five pneumatic valves which isolated the refrigerant in the major system components. The refrigerant was then removed, weighed, and returned to the system. The unit tested was found to have a high initial capacity as migrated refrigerant was removed from the evaporator and then a low, slowly increasing capacity as trapped refrigerant was returned to the system from the accumulator. The unit performance was also compared to single and double time constant regressive approximations and to the time constant calculated from the evaporator mass and heat transfer coefficient. Although relationships between migrated refrigerant and cyclic capacity were observed, no practical refrigerant migration test method that would be less burdensome than the cyclic tests of ASHRAE Std. 116 appears possible at this time.

12. KEY WORDS (Six to twelve entries; alphabetical order; capitalize only proper names; and separate key words by semicolons) central air conditioners; cyclic testing; heat pumps; refrigerant migration

14. NO. OF

PRINTED PAGES

\section{7}

15. Price

X) Order From National Technical Information Service (NTIS), Springfield, VA. 2216I 
